\title{
Reference Process Model for Participatory Budgeting in Germany
}

\author{
Sabrina Scherer and Maria A. Wimmer \\ University of Koblenz-Landau, Research Group E-Government, \\ Universitaetsstrasse 1, 56070 Koblenz, Germany \\ \{scherer, wimmer\}@uni-koblenz.de \\ http://www.uni-koblenz.de/agvinf/
}

\begin{abstract}
Participatory budgeting has become a popular application of e-participation in Germany. About one hundred local governments have executed participatory budgets in the last year. Citizen participation in public budget planning is not formally requested by law in Germany. Also, the legal procedures to settle the budget of a local governments are not defined in detail. In consequence, different procedures exist, which lead also to different implementations of procedures in participatory budgeting. In this contribution, process models for (participatory) budgeting are investigated and a reference process model for traditional budget planning and online participatory budgeting is developed. Reference process models support cities and municipalities to assess the added value and to estimate the human and financial resources to execute participatory budgeting. Hence, comprehensive reference process models are helpful instruments for local governments to decide whether to perform participatory budgeting or not. They are also contributing to successful e-participation endeavors by providing conceptual models (blueprints) for scoping the activities to engage with citizens from the beginning of planning till the evaluation of impact and outcomes.
\end{abstract}

Keywords: E-participation, Participatory Budgeting, Process Model, Reference Model.

\section{Introduction}

Interest in local participatory budgeting in Germany arose in the late 1990s. During this time, the first municipalities in Germany started to let their citizens take part in the annual budget planning to the extent permitted by law. Since then, the engagement of citizens in local participatory budgeting has increased, especially through the support of foundations, ministries and local government organizations [17. At present, 106 German municipalities are running participatory budgeting projects and further 9 municipalities have made a formal decision to introduce participatory budgeting in their local environment 1 .

${ }^{1}$ See 5 th status report available under http://www. buergerhaushalt.org/category/grundlagen/ and overview of municipalities with their status of decision or discussion under http://www.buergerhaushalt.org/status (last accessed 21st June, 2012)

E. Tambouris, A. Macintosh, and Øystein Sæbø (Eds.): ePart 2012, LNCS 7444, pp. 97-111, 2012.

(C) IFIP International Federation for Information Processing 2012 
Investigations in legal grounds have unveiled that participatory budgeting is not regulated by law. Legal grounds for municipal budgets in Germany only regulate the formal procedures within the public administration and the municipal council. Procedures to involve citizens in settling budgets of municipalities are not foreseen in the traditional budget planning procedures in Germany. However since the increased diffusion of the Internet, web platforms for online participatory budgeting have become popular. The participatory budgeting offers in German municipalities involve numerous ways of information and different levels of engagement as we will introduce later on. In earlier works, we argued that the successful introduction of e-participation requires the adaptation of given processes or even the introduction of new processes in the dialogue among citizens and politicians and/or local government officials when introducing online means 33. Due to the lack of regulatory grounds, the procedures and extent of engaging citizens in on- and offline participatory budgeting offers differ widely.

Millard advocates the development of concrete practical recommendations for e-participation in a study for the European Commission [21. Currently, publicly available and scientifically grounded guidelines barely exist for how to successfully introduce participatory budgeting in local governments. In Germany, administrations are therefore often consulted by private companies to introduce participatory budgeting. The lack of publicly available reference models guiding governments at local level to introduce e-participation offers resulted in many different approaches, which are in most cases kept confidential due to the business models of private firms. Municipalities, which intend to introduce e-participation, have difficulties to assess the implications and (financial and human) resources needed to introduce e-participation offers. Since the planning, organization and running of a participatory budget does mean big efforts for a city or municipality, this paper investigates and develops a reference process model for participatory budgeting procedures and therewith extends the reference procedural model (see [33 34] ) with particular reference process models for participatory budgeting.

The remainder of the paper is as follows: next section introduces the theoretical background on public and participatory budgeting at local level in Germany. Section 3 provides a basic understanding of reference process models in literature. An investigation of related work in terms of reference process modeling in e-participation in section 4 concludes the analytical part of the paper. Section 5 describes the research design for developing the reference process models in participatory budgeting. The process model for traditional budgeting at municipal level is introduced in section [6] while the reference process model for participatory budgeting is presented in section 7 . We conclude with a discussion of reference process modeling and the added value thereof in e-participation (see section 8).

\section{Budgeting in Germany}

\subsection{Traditional Communal Budgeting in Germany}

The German Constitution regulates in its art. 28 (2) the autonomy of local governments (municipalities and cities). This includes independence and self- 
responsibility in financial aspects. The municipalities are authorized by the budget bye-law of each particular German State to enact a budget bye-law for each fiscal year 12. Bye-laws of the German States incorporate formal procedures to establish the budget plans of a city or municipality for the upcoming year. Based on this legal ground, local governments build up their annual budgets according to their individual bye-laws (Gemeindehaushaltsverordnung - GemHVO of each city or municipality).

Through communal budgeting and the setting of revenues and expenses involved, the local capacity to act in the following year is determined. The most comprehensive part of the budget bye-law is the budget. The communal budget governs the financial resources for the obligatory tasks (as e.g. police and school), optional tasks (as e.g. sport and cultural offers) as well as internal tasks (as e.g. controlling, administration) of the municipalities. The budget has impact on the citizens and companies within the territory, in some cases also on visitors (as e.g. tourists, commuters).

The process to draft the communal budget is not explicitly defined in the bye-laws of the German States, so that each municipality can arrange the process according to its own preferences and practices. All bye-laws contain the regulation that the budget bye-law is to be deliberated and decided only by the municipal council in a public session [2].

In general, the traditional procedure to set up a budget for the year to come does not foresee any involvement of citizens in the planning of the budget. Direct influence of citizens on the budget bye-law and thus on the budget (e.g. through citizens' decisions or petitions for a referendum) is even forbidden by law in German States, except in Berlin, North Rhine-Westphalia, and Saxony. In these States, statutory provisions in the bye-laws entitle citizens to get access to the draft budget plans (before enacting) and allow them to raise objections in written form. These objections need to be debated in a public session of the council. After the bye-law is in force, no objections can be raised formally any more. The bye-laws of the other 13 German States do not contain any statutory provisions for a right of access or objections. Since municipalities are autonomous, they are allowed to entitle citizens to participate in the budget planning (as this is not forbidden in the bye-laws). To conclude the legal investigations, citizens' participation is generally possible at municipal level, as the bye-laws do not preclude this.

As a consequence of complex budgeting procedures in German local governments, only a very limited number of municipalities or cities applies currently participatory budgeting (less than $1 \%$ of German cities and municipalities). Since the budget of local governments has an impact on the interests and the living quality of citizens and firms settled in the territory, this is quite astonishing. The main question for the investigation at hand is therefore to understand how the process of preparing a municipal budget is formed, which participation possibilities exist for citizens and how to integrate a participatory budget in the traditional process of municipal budget planning. We argue that reference 
process models and guidelines to perform participatory budgeting online and offline can support successful implementation of local budgeting procedures.

\subsection{Participatory Budgeting}

Porto Alegre (Brazil), which implemented the first participatory budget in 1989 to fight corruption in administrations 3536, is one of the most studied cases in the field of participatory budgeting (see e.g. 4[1522]). Participatory budgeting in Porto Alegre is running throughout the year and composed of four main phases [15, p. 54]: (1) prioritizing topics through citizenship, (2) elaborating the budget proposal, (3) enacting the budget in city council and (4) elaborating, implementation and control of the investment plan.

Turning focus onto the German territory, participatory budgeting is implemented since the late 1990s on communal level. Participatory budgets in Germany aim at providing citizens the possibility to have influence on the prioritization of distributing public budget to particular communal tasks and duties. Participatory budgeting in Germany is not a form of direct democracy, because the budget law rests with the municipal and city councils. The implementation of participatory budgeting varies broadly on how citizens can express their ideas and proposals and how these can be integrated and considered in the budget 8 16 13 12. Below, the aims, target groups, criteria for participatory budgets, phases of, and cycle for participatory budgeting are summarized:

Aims. [8, p. 9], 9, p. 10], [16, p. 5] and [24] affiliate the following aims with participatory budgets:

- Acceptance. Increase citizens' acceptance and legitimacy in the realization of local political decisions and political aims.

- Accountability. Reinforce accountability of local and regional governments.

- Efficiency. Support administrations in their tasks.

- Decision support. Provide decision support for politicians through consultation with citizenship.

- Transparency. Provide transparent budgets and budgeting procedures to citizenship.

- Democratization. Reduce disenchantment with politics and democracy through citizens' participation.

- Solidarity. Support citizens among each other in their concerns.

Target groups. In general, no specific target group is specified for participatory budgeting. All citizens - independent from age and education — should have the opportunity to provide their suggestions to drafts of public budgets. As the Internet enables access from anywhere and by everybody, some discussion is recognized about whether contributors to participatory budgeting discourses should be limited to citizens living in the territory of the local government. Particular investigations of this issue could not be found in literature, though. 
Criteria for participatory budgets. Since no particular regulations exist for participatory budgets, a set of criteria is put forward in [27, p. 13] to determine whether citizens' participation in budgeting is a participatory budgeting:

1. Focus. The focus of citizens' participation in the budget lays on financial issues with limited resources.

2. Scope. The participation takes place in a whole city or a district with own political and administrative competences and with it's own administration.

3. Regular effort. It is a question of a lasting and repeated procedure. A onetime open council concerning financial issues is not a participatory budget.

4. Public debate. The process of participatory budgeting bases on independent public debates, whereby the medium (e.g. Internet, councils) can be chosen freely. Written-only surveys on budget financing or a public council meeting are not considered as participatory budgets.

5. Accountability publicly accessible. Statements of account about the results of the participation phase must be available and accessible to the general public.

Phases of participatory budgeting. Communal budgeting phases — and participatory budgeting alike - , can vary, because no statutory provision is in place. [8, p. 14], [14, p. $77 \mathrm{ff}]$, [16, p. 9 ff.] and [20, p. 36] suggest five phases:

1. Initiation and Design. Initiation of the project includes the decision on the implementation of the participatory budgeting project, and formulation of objectives. It also includes the draft of the budget, in which the council is elaborating the conditions of the budget.

2. Preparation. Design of the project including design of participation processes and selection of technical tools.

3. Implementation. Implementation and preparation of the project including implementation of technical components, preparation of documents, and marketing strategy.

4. Realization. Realization of participatory budgeting with the following subphases:

- Information. Citizens are informed through different channels about the budget, the content and procedure of the budgeting.

- Participation. Citizens' participation in budgeting with focus on the development and rating of proposals.

- Decision-making. The panel (usually a city or municipal council) debates the proposals of the participation endeavor and their implementation.

- Accountability. To ensure the plausibility and acceptance of participatory budgets, account for budget decisions and their implementation is to be given by the city or municipal council.

5. Evaluation. Evaluation has twofold purposes: (a) evaluation of the participatory budgeting project against its objectives in regards to expectations and impact achieved; and (b) evaluation of needs for improvement in a next iteration of participatory budgeting. 
Above synthesis of literature indicates the existence of general recommendations and guidelines for performing participatory budgeting at municipal level in Germany. The form of documentation is usually in text format. Reference process models could not be found in the sources investigated. Based on the aims of the paper, next section provides an understanding of reference process modeling from literature.

\section{$3 \quad$ Reference Process Modeling}

A reference model is a conceptual model that can be reused in a multitude of ways. Many definitions exist for reference models [3073810]. 10] distinguish three features of reference models, which the authors extracted from literature (p. 4): (a) a reference model provides recommended or best practices; (b) a reference model does not represent a particular enterprise, but a class of domains and is valid for this; and (c) reference models can be understood as blueprints for information systems development. 10] argue that not all of these characteristics are in agreement with other authors. 39] focuses for example on the aspect that a reference model is used to support the "construction of other models" (p. 491), i.e. as blueprint for the development of other models. The "Design by Reuse Paradigm" of reference modeling is also used e.g. in [1928. Reference models, which are used as blueprints for the construction of other models or as "model patterns" [11, usually need to be adapted to the particular application case [28. However, the reuse of existing conceptual models facilitates and usually speeds up the development of an information system environment as is strongly recommended in enterprise architecture literature (see e.g. 32]).

The research in this paper bases on the "Design by Reuse Paradigm" for reference models. The aim is to base the reference models on recommended practices of participatory budgeting and to provide a reference process model of a "participation process" view as blueprint, which is commonly practiced in information systems development 39112832. Thereby, a visual business process model serves as a formal presentation of the participatory budgeting procedure in order to minimize the possibility for different interpretations of the same model (as argued in [3]). Visual presentations support the stakeholders in understanding the models (ibid). Van der Aalst et al use the term business process modeling "to characterize the identification and (typically rather informal) specification of the business processes at hand" [3, p. 8]. The authors include the "modeling of activities and their causal and temporal relationships as well as specific business rules that process executions have to comply with" in this definition [3. p. 8]. Our understanding of designing and using reference process models for participatory budgeting is based on this concept of business process modeling.

\section{Related Work}

Reference models and reference process models for e-government exist for a while (see e.g. 6 29] ), but only a few target e-participation. Based on the participatory 
budgeting approach in Cologne and other German cities, 20. propose a guideline for communal e-participation projects, which includes a business process modeling for parts of the participatory budgeting procedure. The authors use event-driven process chains (EPC) as notion for the process model. The process models in 20] do not detail the participation phase, though.

Comparable with a reference process model language for e-participation is the approach of Ali et al, which proposes a collaboration pattern language to design architectures for e-participation systems [5]. The aim of their approach is to provide guidance to help the designers of e-participation systems to choose suitable collaborative technologies. The proposed pattern language is based on the work in the areas of collaboration engineering and software engineering. The main tasks proposed in the approach focus on the selection of adequate collaboration patterns [5]: develop a high-level participation description; develop a use context diagram; identify collaborative participation family; select relevant atomic collaboration patterns; and map collaboration patterns onto technology patterns. The approach focuses on the design phase of an e-participation project. It does not present any particular participation process model in terms of a business process model for e-participation.

The investigations on reference process models for e-participation have unveiled that process models for e-participation barely exist as general reference process models. We therefore develop a reference process model for participatory budgeting in Germany. Next section introduces the underlying research design, while the reference process models are presented thereafter.

\section{$5 \quad$ Research Design}

The research design to develop reference process models for e-participation started with a literature study. The research involved investigation of reference process models in different e-participation areas (including the e-participation domains consultation, urban planning, lobbying, petitioning and participatory budgeting). For the sake of space, this paper focuses solely on the domain of participatory budgeting. The literature investigation resulted in an insight into the procedures and respective legal grounds of budgeting at communal level in Germany (cf. sections 2.1 and 2.2). It unveiled the lack of reference process models for the domain (cf. summary in section 4 for the related work). Subsequently, case analysis of existing participatory budgeting projects (including completed and running projects) in Germany was conducted. A selection of participatory budgeting projects was chosen for the investigation of process models to derive a reference process model. The selection is based on a list of criteria, including actuality of the project, impact reached, quality of the processes, results and the platform. As a result, three German participatory budgeting projects have been selected for analysis: Cologn $2^{2}$, Hilden 3 , and Berlin-Lichtenberg. These cities

\footnotetext{
2 https://buergerhaushalt.stadt-koeln.de, see also 37.

3 http://www.hilden.de/online/board/index.php, see also 8

4 http://www.buergerhaushalt-lichtenberg.de, see also 18
} 
implement participatory budgeting for several years and have frequently advanced the projects. In addition, they pursue different approaches regarding type of proposed topics, rating of proposals, use of the participation platform and the Internet, so that the source of information for the reference process model is sufficiently large and suitable for developing a reference process model.

The development aimed at deriving a reference process model for the traditional public budgeting procedure as well as one for the (online) participatory budgeting procedure at local level in Germany. First, the traditional budgeting process has been designed and modeled. Then, the models for the participatory budgeting process supported by e-participation platforms has been elaborated. Modeling of processes is performed in Business Process Modeling Notation (BPMN). This notation was chosen because of its expressive power [23, which supports modeling of typical business processes [26]. BPMN is used for process documentation and optimization, communication among stakeholders and business analysts as well as for technical purposes (as e.g. process simulation) 25. BPMN was favored over other modeling notations (e.g. event-driven Process Chains (EPC) [31]), because it is standardized and widely known on international scale. Besides being an international standard notion and having wider expressiveness, BPMN was also selected as it offers the possibility to declare process ownerships represented in pools with swim-lanes.

\section{Process Model for Traditional Participatory Budgeting}

The traditional process refers to the procedure of communal budgeting as described in section 2.1. The phases have the following structure and content:

Preparation of the budget. In this phase, the preparation of the budget starts based on usual bottom-up budgeting, in which the chamberlain asks the administrative offices for notifications of demand. After preparation of a first administrative draft, the chief officers and mayors are consolidating this draft. Following, the chamberlain prepares the draft of the budget bye-law.

Debate. In this phase, the expert and finance committees are debating the budget bye-law to prepare it for the final agreement and Enactment. In the cases where citizens are entitled to take opposition against the budget, the budget is laid open to public inspection for a given period. During this phase (usually 14 days), citizens can raise a plea in written form. The public inspection needs to be announced based on the bye-law in the customary proedures in a place. The arguments handed in during the public inspection phase are discussed by the expert and finance committee and included in the draft budget bye-law if relevant and reasonable.

Enactment. The focus in this phase lays on the public session of the municipal council, in which the draft budget bye-law and herewith the budget itself is decided. This session is regulated by law in all States in Germany. If citizens raised pleas, these are consolidated in the public session of the council. The 
citizens have no right of co-determination in the budget bye-law and therewith also not for the budget. The result of the public session is the decided budged bye-law.

Financial control and entry into force. The budget is controlled by the regulatory authority in the case this is regulated by law. Finally the decided budget is laid open to public inspection for usually 7 working days and the budget bye-law comes into effect by the first January of the next year.

Monitoring and accountability. In the last phase, the budget bye-law enacted is monitored and controlled along and after the end of the year it was in force. The audit court may inspect the implementation of the bye-law and in any case, the mayors have to give account for the spending of the past year in subsequent council meetings. Any conspicuous features have to be explained and resolved. Lessons from the penultimate year feed into the budget planning of the next year, starting again with phase 1 .

The reference process model for the traditional procedure is visualized in Figure 1, lower stream of the process model. The model describes the coarsegrained view of the reference process model for both, traditional (lower part) and participatory budgeting (upper part). The tasks of each phase of budgeting are decomposed into more detailed models in a subsequent step. For the sake of space, these modes are omitted in this publication.

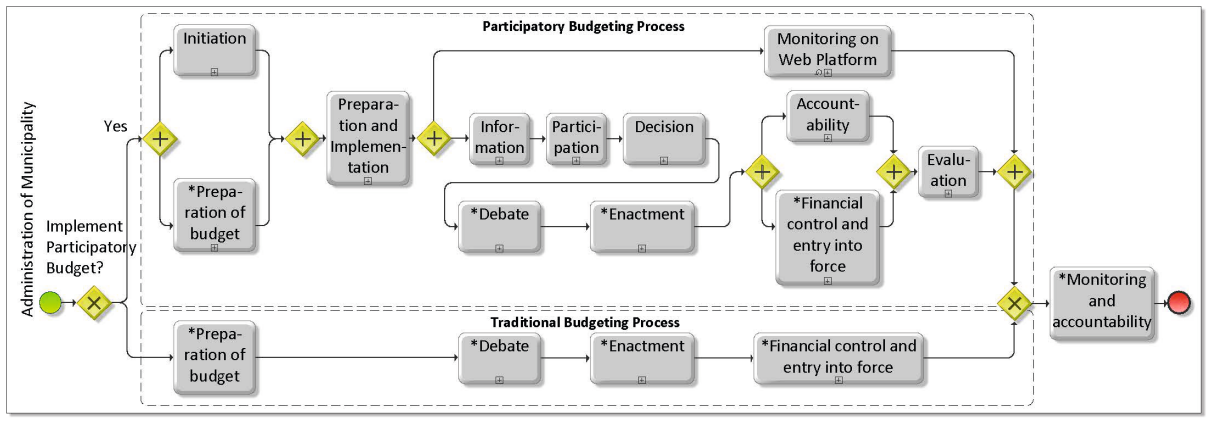

Fig. 1. Reference process model for annual public budgeting (lower part) and participatory budgeting (upper part) at communal level in BPMN notation. The * indicate steps regulated by law.

\section{Reference Process Model for Participatory Budgeting}

The reference process model for participatory budgeting with e-participation is visualized in Figure 1 (upper part). The model visualizes the steps grounded in law with an asterisk $\left(^{*}\right)$. In addition to the traditional process phases as described in section 6, the model accommodates the following phases (or revises/extends traditional phases) for participatory budgeting: 
Initiation. In addition to the traditional preparation phase, the organizational structures for the implementation of the participatory budget are to be settled. Also, planning tasks for the online participation as e.g. instruments, contents, deadlines, public relations, marketing etc. are to be coordinated and initiated. Parallel to this phase, budget consultations are taking place inside the local administration (see task "*Preparation of budget" in section 6).

Preparation and implementation. First part in this phase is to set up the web platform and other technical means. Besides that, the topics of the participatory budgets are decided. The latter may involve citizens. However, the experiences from the three projects analyzed indicate that settling the topics to be discussed in the participatory budgeting by administrations is accepted by citizens. Hence, the reference process model does not foresee a collaborative step to determine the topics of discussion in participatory budgeting. This way, also time is saved in the preparatory phase. Another task in this phase is the preparation of media material as e.g. printing of brochures, contacting media.

Information. This phase aims to reach all citizens with different channels with the purpose to inform them and invite them to participatory budgeting. In many cases, a kick-off is held as an opening session, where citizens get all necessary information about cycle, aims, participation methods etc. of the participatory budgeting initiative. Information about the budget and the corresponding financial dependencies are to be presented in a transparent and easy understandable manner. The preparation and dissemination of information needs to ensure that all relevant target groups are addressed, including underrepresented groups. Plurality in media is important to inform all citizens likewise. Thereby, limited time as well as receptiveness of citizens is to be kept in mind.

Participation. This phase tackles the real participation of citizens. It has to be transparent and traceable and is divided into two sub-processes: (a) enable citizens to provide proposals, and (b) citizens rate and comment proposals. The means to express comments and proposals must enable different channels and ways. The central point is the participation platform, which usually embodies different e-participation tools such as discussion forum, wiki, etc. Citizens are invited to post their proposals through the online platform. Other possibilities to submit proposals are oral or written interventions at consultation hours or inputs provided during public sessions, submission of proposals by phone or by post. All proposals submitted through alternative ways are transferred to the participation platform by editorial staff and can be viewed by all citizens. To ensure that all citizens have the same participation opportunities, PCs with internet access can be provided free of charge in public buildings. In the second sub-process, the option to submit further proposals is closed. Submitted proposals can be commented and rated. The result of the overall participation phase is a ranking list, which contains the best ranked proposals. A moderator accompanies the participation and sums up the contributions from citizens. Figure 2 visualizes the corresponding detailed reference process model for the participation phase. 

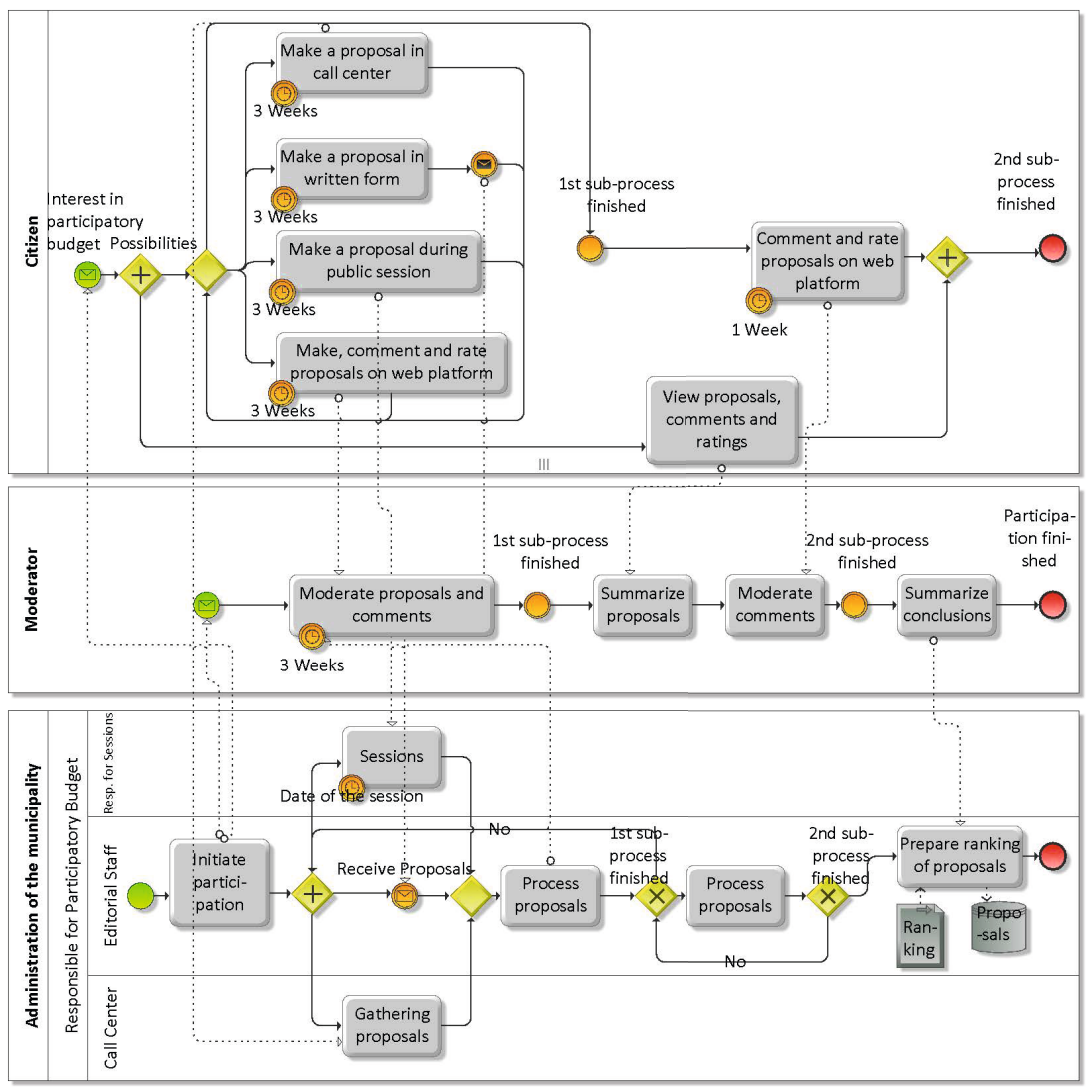

Fig. 2. Detailed process model for the participation phase of the overall reference process model of participatory budgeting (see upper part of Figure 1)

Decision. The results from the participation phase must be taken into account by the local council. In the decision phase of the participatory budgeting, the ranked proposals from the deliberation are discussed in a committee - usually set up by the city or municipal council. This committee advises on the inclusion of the proposals in the public budget and their implementation. Affiliated costs and plans for implementing the proposals through the administration are to be prepared transparently. The results of the consultation are to be made available to citizens on the web platform.

Accountability. Here, account is given about accepted and refused proposals. Accounts have to be formulated in a comprehensible way and must be easily available to all citizens. A time frame regarding the implementation of accepted proposals is to be included. Citizens are informed through the media already used in the information phase as these are familiar to them. 
Evaluation. The evaluation phase concludes the participatory budgeting endeavor. Evaluation analyzes limitations and problems of the participatory budget and the affiliated process of citizen participation. It also assesses impact of, and transparency in the public participation through different means. Insights from evaluation help to avoid similar problems and issues in the next iteration of participatory budgeting. The evaluation has to directly incorporate citizens with questionnaires, in which they can report the pros and cons of the participatory budget. In addition, an independent organization can perform an assessment of the endeavor in regards to its objectives, process and principles followed along the participation process.

The phases of traditional public budgeting have already been described in section 6 and are not repeated here. Next section discusses the differences and added value of reference process models as conceptual models for e-participation.

\section{Discussion and Added Value of Reference Process Models for E-Participation}

The reference process model in Figure 1 shows differences between traditional and participatory budgeting: while the traditional process looks more straightforward and tiny, the participatory budgeting process contains more phases, as the participation steps need to be integrated in the traditional process. The participation process is detailed in Figure 2. The reference process model shows that participatory budgeting requires careful planning and investment of resources to perform such an endeavor successfully. The research indicates that involving citizens in the budget planning calls on the one hand for more time in the overall process, and resources (financial and human) to deal with the inputs from citizens through a multitude of channels. Also, independent third parties play an important role when it comes to moderate and sum up proposals from citizens for the final rating thereof. If the latter would be performed by the local administration, it would be perceived as intervention from the local government and would therefore not be considered neutral any more. On the other hand, participatory budgeting enables citizens to propose and influence local politics in regards to where taxpayers' money is to be invested. The endeavor also brings more transparency and insight of citizens into the annual budget planning, which in turn may result in a better relation between citizens and local politics. The local administration is thereby considered a supportive body that provides the facilities and implements the participatory budgeting.

The reference process models developed serve as blueprint for local governments to understand the implications of setting up participatory budgeting in their local environments. So far, it has been difficult for local governments to get such understanding without the efforts of external consultancy. The target users of the reference process models as presented here are local public administrations and other interested institutions, which aim at introducing participatory budgeting in their environment. The reference process models are focusing on the German budgeting procedures and legal grounds. 
The reference participation process models such as the ones introduced in this paper complement the e-participation reference framework (see [34]) with a library of blueprints of process models. This way, the reference framework is enriched with concrete instances of model artifacts targeting the process view.

Further research is planned in three directions: first, the reference process model for participatory budgeting is to be analyzed and extended for fitness on international scale. Second, reference process models for other e-participation areas are planned to be added to the library. Third, evaluation of the models in practice will evidence their applicability and and usefulness in practice. Thereby, issues such as actuality and simplicity (vs. sometimes too complex models that contain too much information) of models will be investigated.

Acknowledgment. The authors express their gratitude to Stephan Adams, Carsten Einig, Olaf Gärtner, Marc Vogel and Navid Zarabian. Their analysis of German e-participation processes as research internship at University of Koblenz-Landau under the supervision of the authors build the base for the work at hand. Particular thanks go to Stephan Adams for his thorough analysis of participatory budgeting.

\section{References}

1. Der kommunale Haushaltsplan, 1. Teil - Allgemeine Einleitung und Begriffsdarstellungen. Wegbeschreibung für die kommunale praxis, Friedrich-Ebert Stiftung and Arbeitsgruppe Kommunalpolitik (2003)

2. Der kommunale Haushaltsplan, 6. Teil - Die Aufstellung und Ausführung des Haushaltsplans. Wegbeschreibung für die kommunale praxis, Friedrich-Ebert Stiftung and Arbeitsgruppe Kommunalpolitik (2003)

3. van der Aalst, W.M.P., ter Hofstede, A.H.M., Weske, M.: Business Process Management: A Survey. In: van der Aalst, W.M.P., ter Hofstede, A.H.M., Weske, M. (eds.) BPM 2003. LNCS, vol. 2678, pp. 1-12. Springer, Heidelberg (2003)

4. Abers, R.: Learning democratic practice: distributing government resources through popular participation in Porto Alegre, Brazil. In: Freire, M., Stren, R. (eds.) The Challenge of Urban Government: Policies and Practices, vol. 130. World Bank Publications (2001)

5. Ali, H., Macaulay, L., Zhao, L.: A Collaboration Pattern Language for eParticipation: a Strategy for Reuse. In: Proceedings of the 9th European Conference on e-Government, pp. 29-38. Academic Publishing International, London (2009)

6. Becker, J., Algermissen, L., Delfmann, P., Niehaves, B.: Konstruktion konfigurierbarer Referenzmodelle für die öffentliche Verwaltung. In: Dittrich, K.R., König, W., Oberweis, A., Rannenberg, K., Wahlster, W. (eds.) INFORMATIK 2003 - Innovative Informatikanwendungen, Band 1, P-34, pp. 249-253. Koellen-Verlag for Gesellschaft für Informatik, Bonn (2003)

7. Becker, J., Niehaves, B., Knackstedt, R.: Bezugsrahmen zur epistemologieschen Positionierung der Referenzmodellierung. In: Beckeer, J., Delfmann, P. (eds.) Referenzmodellierung: Grundlagen, Techniken und domänenbezogene Anwendung, pp. 1-18. Physica-Verlag, Heidelberg (2004)

8. Behrens, F., Pröhl, M.: Kommunaler Bürgerhaushalt: Ein Leitfaden für die Praxis. Innenministerium des Landes Nordrhein-Westfalsen, Bertelsmann Stiftung (2004) 
9. Bogumil, J., Holtkamp, L.: Bürgerkommune konkret: Vom Leitbild zur Umsetzung; ein Leitfaden für die kommunale Praxis. Friedrich-Ebert-Stiftung, Stabsabt (2002)

10. Fettke, P., Loos, P.: Perspectives on Reference Modeling. In: Fettke, P., Loos, P. (eds.) Reference modeling for business systems analysis, pp. 1-21. IGI Global (2007)

11. Fettke, P., Loos, P.: Classification of reference models: a methodology and its application. Information Systems and E-Business Management 1, 35-53 (2003)

12. Franzke, J., Kleger, H.: Bürgerhaushalte: Chancen und Grenzen, vol. 36, edition sigma (2010)

13. Ganuza, E.: Bürgerhaushalte in Spanien: Mobilisierung von Bürgerinnen und Bürgern. In: Dokumentation - Internationaler Kongress zu Modellen des Bürgerhaushalt Modelle Bürgerhaushalte, pp. 30-34 (2010)

14. Günther, A.: Der Bürgerhaushalt: Bestandsaufnahme - Erkenntnisse - Bewertung. 1. auflage edn. Boorberg (2007)

15. Herzberg, C.: Der Bürgerhaushalt von Porto Alegre, vol. 9. LIT Verlag, Münster (2002)

16. Herzberg, C.: Bürgerhaushalt in Grossstädten. Bundeszentrale für politische Bildung (2005)

17. Kersting, N.: Politische Beteiligung: Einführung in dialogorientierte Instrumente politischer und gesellschaftlicher Partizipation. Bürgergesellschaft und Demokratie. VS Verlag für Sozialwissenschaften (2008)

18. Klages, H., Daramus, C.: Bürgerhaushalt Berlin-Lichtenberg: Partizipative Haushaltsplanaufstellung, -entscheidung und -kontrolle im Bezirk Lichtenberg von Berlin. Abschlussbericht zur begleitenden Evaluation. Deutsches Forschungsinstitut für Öffentliche Verwaltung (2006)

19. Lee, H., Irani, Z., Osman, I.H., Balci, A., Ozkan, S., Medeni, T.D.: Research note: Toward a reference process model for citizen-oriented evaluation of e-Government services. Transforming Government: People, Process and Policy 2, 297-310 (2008)

20. Märker, O., Wehner, J., Gölz, S.: Leitfaden für kommunale E-PartizipationsVerfahren. Technical report, Fraunhofer IAIS, Zebralog (2009)

21. Millard, J.: eParticipation recommendations - focusing on the European level. Deliverable 5.1, Study and supply services on the development of eParticipation in the EU (2009)

22. Novy, A., Leubolt, B.: Participatory budgeting in Porto Alegre: social innovation and the dialectical relationship of state and civil society. Urban Studies 42, 20232036 (2005)

23. OMG: Business Process Modeling Notation, V2.0. Omg available specification. Object Management Group (OMG) (2011), www.omg.org/spec/BPMN/2.0/

24. Peixoto, T.: Beyond Theory: e-Participatory Budgeting and its Promises for eParticipation. European Journal of ePractice 7, 1-9 (2009),

http://www.epractice.eu/files/7.5.pdf

25. Recker, J.: BPMN Modeling-Who, Where, How and Why. BPTrends 5, 1-8 (2008)

26. Recker, J., Indulska, M., Rosemann, M., Green, P.: How Good is BPMN Really? Insights from Theory and Practice. In: Ljungberg, J., Andersson, M. (eds.) Proceedings 14th European Conference on Information Systems (2006)

27. Röcke, A., Herzberg, C., Bloch, M.: Verfahren und Modelle des Bürgerhaushalts und ihre Umsetzung in Deutschland. In: Dokumentation - Internationaler Kongress zu Modellen des Bürgerhaushalt, pp. S.13-S.21, 13-16 (2010)

28. Rosemann, M., van der Aalst, W.M.P.: A configurable reference modelling language. Information Systems 32, 1-23 (2007) 
29. Schaffroth, M.: R014 - Referenzmodell eGovernment-Portale. Referenzmodell. Informatikstrategieorgan Bund (2006)

30. Scheer, A.W.: ARIS - House of Business Engineering: Konzept zur Beschreibung und Ausführung von Referenzmodellen. In: Becker, J., Rosemann, M., Schütte, R., (eds.): Referenzmodellierung: State-of-the-art und Entwicklungsperspektiven, pp. 2-21. Physica-Verlag (1998)

31. Scheer, A.W.: ARIS - Modellierungsmethoden, Metamodelle, Anwendungen, vol. 4. Springer, Berlin (2001)

32. Schekkerman, J.: Enterprise Architecture Tool Selection Guide, vol. Version 6.3. Institute For Enterprise Architecture Developments (2011),

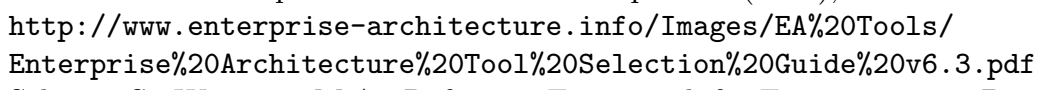

33. Scherer, S., Wimmer, M.A.: Reference Framework for E-participation Projects. In: Tambouris, E., Macintosh, A., de Bruijn, H. (eds.) ePart 2011. LNCS, vol. 6847, pp. 145-156. Springer, Heidelberg (2011)

34. Scherer, S., Wimmer, M.A.: E-participation and Enterprise Architecture Frameworks: An Analysis. Information Polity 17(2) (2012)

35. de Sousa Santos, B.: Participatory budgeting in Porto Alegre: toward a redistributive democracy. Politics and Society 26, 461-510 (1998)

36. Souza, C.: Participatory budgeting in Brazilian cities: limits and possibilities in building democratic institutions. Environment \& Urbanization 13, 159-184 (2001)

37. Taubert, N., Krohn, W., Knobloch, T.: Evaluierung des Kölner Bürgerhaushalts. Tech. rep., University of Bielefeld for the City of Cologne. Technical report (September 2010)

38. Thomas, O.: Das Referenzmodellverständnis in der Wirtschaftsinformatik: Historie, Literaturanalyse und Begriffsexplikation. Institut für Wirtschaftsinformatik im DFKI 187, 5-32 (2006)

39. Thomas, O.: Understanding the Term Reference Model in Information Systems Research: History, Literature Analysis and Explanation. In: Bussler, C.J., Haller, A. (eds.) BPM 2005. LNCS, vol. 3812, pp. 484-496. Springer, Heidelberg (2006) 